\title{
An Econometric Analysis for the Bid-Ask Spread in the Emerging Chilean Capital Market
}

\author{
David Cademartori-Rosso \\ Facultad de Ciencias Económicas y Administrativas \\ Pontificia Universidad Católica de Valparaíso, Chile \\ dcademar@gmail.com \\ Phone: (56) 32-2273512 \\ Berta Silva-Palavecinos \\ Facultad de Ciencias Económicas y Administrativas \\ Pontificia Universidad Católica de Valparaíso, Chile \\ bsilva@pucv.cl \\ Phone: (56) 32-2273329
}

\section{Ricardo Campos-Espinoza}

Facultad de Ciencias Económicas y Administrativas Pontificia Universidad Católica de Valparaíso, Chile ricardo.campos.e@pucv.cl Phone: (56) 32-2273337

\section{Hanns de la Fuente-Mella}

Facultad de Ciencias Económicas y Administrativas Pontificia Universidad Católica de Valparaíso, Chile hanns.delafuente@pucv.cl

Phone: (56) 32-2273328

\begin{abstract}
The purpose of this paper is to show that different methods for calculating the spread (Bid-Ask) and the methods for annualizing intra-day data affect the results of econometric models. To achieve our goal, we analyze different econometric models in the context of:

i) the International Financial Reporting Standards (IFRS) adoption,

ii) the reduction of information asymmetry due to new corporate governance standards, and

iii) the ownership concentration that characterize the Chilean Capital Market. We test the quality of the information delivered to the market using two information disclosure indices (DIS and Botosan).
\end{abstract}

We find that the definition of spread and the methods for annualizing intraday data it is a key decision and may affect the statistical significance of the variables of a specific model.

\section{JEL Classification:}

Keywords: Spread (Bid-Ask), Econometric Modeling, IFRS, Information Asymmetry, Information Disclosure. 


\section{INTRODUCTION}

The paper's purpose is to show the effect of choosing different spread definitions for modeling the relationship between information asymmetry and information disclosed by corporations that quote in the Chilean Capital Markets. Different methods for annualizing intraday data are, moreover, tested. The spread (Bid-Ask) calculated on intra-day shares from the Santiago Stock Exchange for 2007-2012 will be used as a proxy for information asymmetry. The quality of information provided to the capital markets is measured by two information disclosure indices (DIS and Botosan), in the context of IFRS adoption by Chilean accounting standards.

The paper contributes to the literature by offering an analysis that the definition of spread is not neutral and may affect the robustness of the different models we analyze. We test this in a small market with highly concentrated ownership. The average ownership share of the majority shareholder of the 40 stock son the Selective Stock Price Index (IPSA, in Spanish) is $41 \%$, whereas in a random sample of 100 companies from the S\&P 500, this share amounts to only 9\% (Rubin, 2007; Coloma, 2010; Rapaport and Sheng, 2010). The market is primarily regulated by the Public Corporate Act and Stock Market Act, which are being modified to adjust to a globalized market and to protect minority shareholders. In the same context, the Superintendence Supervision of Securities and Insurance (SVS, in Spanish) plays an important role in issuing regulations that require sound practices in legal and corporate governance. In this paper, we analyze the effects on the Chilean market of adopting IFRS. Additionally, we consider it is necessary to identify whether a given company analyzed was listed on the IPSA in a given year because this factor will affect the instrument's liquidity.

The reminder of this paper is organize as follows, section II contains the literature review, section III describes the materials and methods, section IV analyzes the results and section V shows the conclusions and research implications.

\section{LITERATURE REVIEW}

Market efficiency is a central element of economic theory, and its importance is derived from the fact that the more efficient the markets are, the better resource allocation becomes. Many authors conclude that with lower levels of information asymmetry come lower costs of private equity, which in turn affects company growth and profitability (Gompers, Ishi and Metrick, 2003; Khurana, Pereira and Martin, 2006; Fu, Kraft and Zhang, 2012; Ghoul, Guedhami, Ni, Pittman and Saadi, 2013). Munteanu (2011) concludes in an extensive literature review that companies that seriously and voluntarily adopt IFRS observe a decrease in the cost of capital, while also finding that when the adoption is mandatory the quality of information is lower, albeit not significantly so. Armstrong, Barth, Jagolinger and Riedl (2010) analyze the impact of 16 events associated with the adoption of IFRS in Europe and conclude that adoption decreases the cost of capital, particularly in companies in which the quality of information was low and information asymmetry high prior to the adoption.

In the literature, there is also evidence of an existing relation between corporate governance and information asymmetry. For example, Cormier, Ledoux, Magnan and Aerts (2010) relate the quality of corporate governance, among other variables, with the number of independent directors and leverage (relative debt). Healy and Palepu (2001) develop a substantial literature review on the relation between disclosure decisions by management and their effects in the capital market. They conclude that demand for additional information disclosure is a response to agency problems between management and external investors. Kanagaretnam, Lobo and Whalen (2007) demonstrate that better corporate governance results in less information asymmetry. In their model, they relate the spread with variables such as independent directors and other features of the board, using company size as one control variable. 
In addition, the quality of corporate governance has been measured by various indices. However, there is no general consensus on the matter. Verrecchia (2001) constructed a taxonomy of the indices and distinguished three types: indices based on associativity, discretionality and efficiency. The indices based on associativity measure the effect of disclosing one event on the behavior of investors and stake holders with reference to prices and transaction volumes (Lintner; 1969; Karpoff, 1987). The second index type measures the degree of discretion exercised by managers in information disclosure to positively influence company value (Trueman, 1986; Gigler and Hemmer, 1999). For disclosure indices based on efficiency, the efficacy of management establishing an information disclosure policy is measured in the absence of a priori knowledge (Marshall, 1974; Kunkel, 1982). There are many options for calculating the indices. One option is measurement at the request of the company being assessed, for example, when Standard and Poor's (2006) conducts an assessment at the request of a client. Another way to calculate the index of corporate governance quality is based on available public information. This approach is in line with the proposal of Haat, Mahenthiran, Rahman and Hamid (2006), who investigated a 17-item information disclosure index (DIS) that integrated aspects of information quality disclosed. Another proposal is an index constructed by Botosan (1997), which consists of 138 items in 18 groups and includes a wide spectrum of corporate information features disclosed', e.g., strategic information from the company, cash flow projections and segment information.

One way to measure information asymmetry is using the spread (Copeland and Galai, 1983), under the assumption that when market participants possess similar information, the spread should be lower. Traders expand the Bid-Ask to cover losses that result from possible information asymmetry (Glosten and Harris, 1998).

Additionally, the spread is considered to be a transaction cost for agents who wish to conduct a rapid exchange of shares for money. This difference is the compensation for the traders for operating without significant delay (Chan and Chung, 2012). The pace of exchange can be increased with narrower price movements by offering a smaller Bid-Ask. In competitive conditions, the Bid-Ask will measure the cost of conducting non-delayed operations (Demsetz, 1968). Thus, dealers offer immediate exchange, matching purchase and sale orders and maintaining inventories for orders that cannot be matched (Benston and Hagerman, 1974). Various studies have used the dealer spread to assess an increase in information asymmetry prior to an anticipated disclosure of an event, such as the publication of results or dividends by a company (Venkatesh and Chiang, 1986). The ways to calculate the spread and its modeling (Bollen, Smith and Whaley, 2004; Amihud and Mendelson, 1989) are not insignificant. The financial literature has used various measures of the spread. The spread can be calculated absolutely or relatively, in its original or modified scale, with or without the effect of past prices of the same shares or based only on put or call orders versus those which include the transfer price (see Table 1). Furthermore, the spread can be measured over different time periods (e.g., intra-day, daily, monthly, quarterly). To cite only a few examples of time measurement, Kanagaretnam et al. (2007) studied whether good corporate governance practices reduce information asymmetry near the time of publishing quarterly results and described the spread variable as the difference between the average percentage margin for each of the four days of the period during which results were announced and the average for a non-event period. Chen, Chung, Lee and Liao (2007) calculated the spread using the McInish and Wood (1992) formula, where by the stock quotation is considered in seconds and the number of seconds of daily negotiation is also observed.

Another approach is to estimate the spread instead of calculating the true spread, Roll (1984), Corwin and Schultz (2012); Corwin and Schultz shows that the estimate of the cross-sectionalcorrelation coefficient, high-low spread estimator and the true spread is about 0.9. Harris (1990) suggest that the Roll Bid-Ask spread model assumes that the underlying stock value follows a random walk that buy and sell orders are equally probable and serially independent, and that underlying value is independent of the order flow. 
Table 1.

Main measures on the spread observed in the financial literature

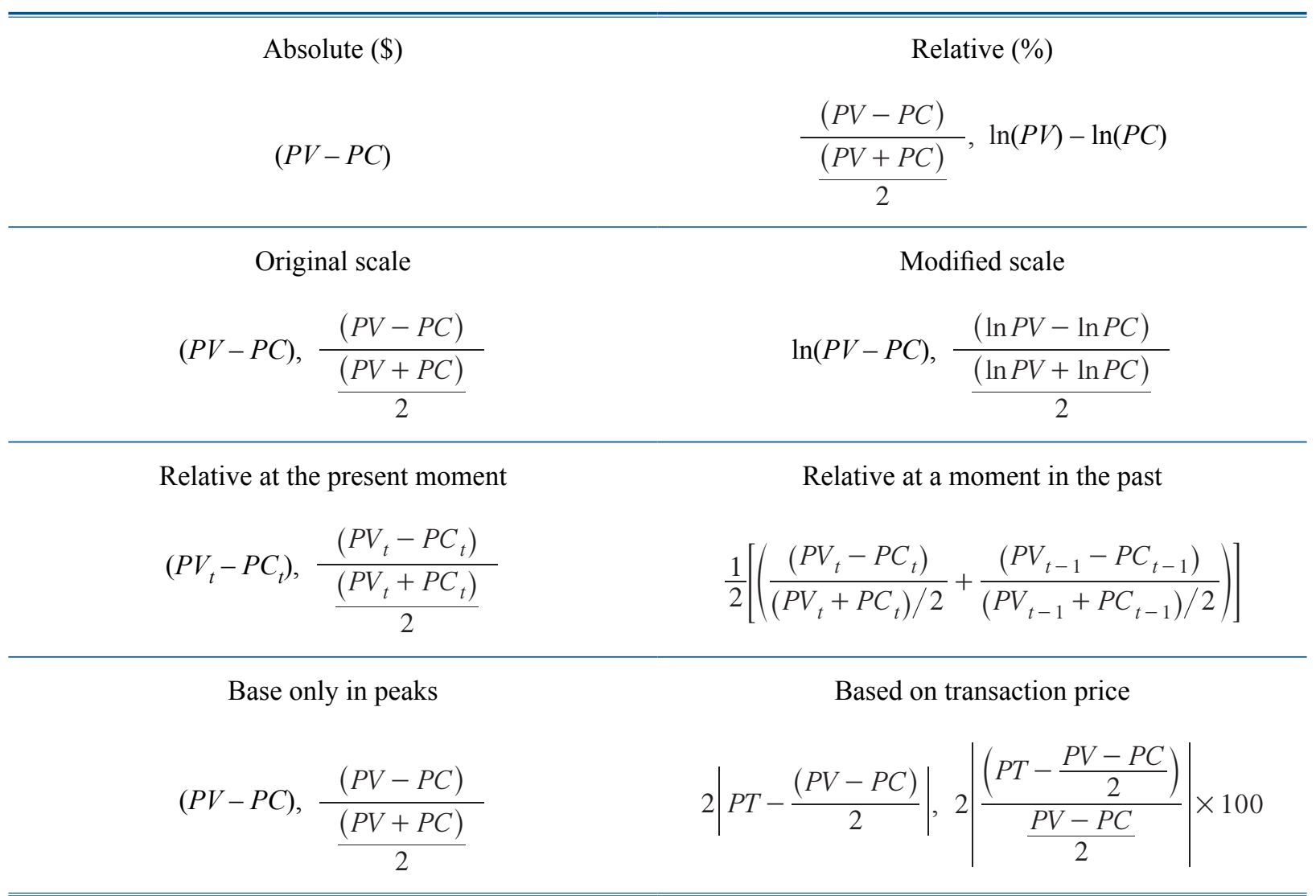

In Table 1, $P C$ is the purchase price of the request made, $P V$ is the selling price of the request made, $P T$ is the price of the transactions actually performed.

Regarding institutional investor participation in company owner ship, it is worth noting that the Organization for Economic Co-operation and Development (OECD) (2011, p. 3) views the role of institutional investors in Latin America as more critical than in others parts of the world in "supporting the development of the markets in order for them to function properly and be sustained by good corporate governance practices". This importance results from the high ownership concentration that prevails in Latin American markets and the existence of risk for minority shareholders. Dennis and Weston (2001) found that the relation between institutional equity and the spread is negative and significant as opposed to Sarin, Shastri and Shastri (1996), who found a significant (positive) relation. In general, Dennis and Weston's results indicate diminished liquidity with concentrated ownership.

Our study considered the participation of institutional investors in the ownership of sample companies, which provides them the right to an independent director ${ }^{1}$. Additionally, to visualize the concentration of ownership in the Chilean market, which significantly affects liquidity, Rubin (2007) identified the ownership controlled by the five largest shareholders.

Florou and Pope (2012) analyze the effects of IFRS adoption and conclude that the better quality of financial statements has influenced the behavior of institutional investors. Soderstrom and Sun (2007) demonstrate that the impact of IFRS adoption depends on the economic and legal environment. The same processes do not occur in countries in which the legal system is based on the French civil code or on Common 1] Law. Greenstein and Sami (1994) analyze the effects of the Securities and Exchange Commission's (SEC) regulations on the obligation to report by

The "Enersis Case" persuasively argues for the importance of independent directors. In this case, the independent director and the Chilean pension fund representatives requested a ruling from the SVS on the relative increase in capital proposed by the majority shareholders of Enersis S.A. and forced the company to disclose information on its investment plan (Economía y Negocios, 2012). 
segments on the spread and demonstrate that these regulations decreased the spread. Assidi and Omri (2012) demonstrate that among the companies on the Paris stock exchange that comprise the CAC 40 index, the companies that adopted the IFRS significantly improved the quality of information and mitigated information asymmetries, both measured by the Kothari, Leone and Wasley (2005) model.

Bakhshi, Bazrafshan, Rezaei and Fereidouni (2011) analyzed the effects of corporate governance on the spread, specifically in reference to equity held by company management and independent directors. These authors concluded that the spread increases when management has a larger stake and decreases when the majority of shares are owned by other investors; particularly, institutional investors and independent directors.

When a company is traded on the home country stock exchange and on the North American stock capital market, it is necessary to control the model data for a variable that differentiates the American Depositary Receipts (ADR) because such companies are subject to different regulations regarding the disclosure of public information. The issuance of ADR simplies the adoption of regulations additional to those that apply in the country in which the shares are originally traded (i.e., the US SEC regulations on trading on the New York Stock Exchange (NYSE)). These additional regulations require additional shareholder protection compared with the regulations in place in emerging countries (Chung, 2006). This additional protection results in less information asymmetry, and, therefore, the spread becomes narrower.

Lin, Sanger and Booth (1995) examine the relation between the transaction volume and the spread and conclude that volume is positively related to the average spread. In addition, they observe that the transaction volume is different at different times of day, with a higher volume during the first hours of trading, when pending transactions from the previous day are being concluded.

As noted in the literature review, the hypotheses presented in this investigation are as follows:

Hypothesis 1. The definition of spread used affects the robustness of the model.

Hypothesis 2. The method used to annualize intra-day data affects the robustness of the model.

\section{MATERIALS AND METHODS}

Exploratory empirical analysis is conducted on a sample of 12 companies traded on the Santiago de Chile Stock Exchange, whose trading names are: Aguas-A, Andina-B, Antarchile, Colbún, Conchatoro, Copec, CTC-A, Endesa, IAM, Masisa, Ripley and SK. The majority of the selected companies maintained a presence on the IPSA for the entire 2007-2012 period. The sample companies represent $27 \%$ of the total market capitalization of the companies traded on the IPSA (the 40 most important companies) as of December 2012. On average, these companies conduct 33,850 annual stock market transactions (in 2012), which is more than the average transaction count of all of the publicly-traded companies in Chile $(15,283)$.

The data related to stock market operations were obtained directly from the Santiago Stock Exchange, and the data on the companies and the quality of their publicly available information were obtained from financial statements acquired from the SVS. All of the data are annual and synthesize the transactions of the companies during the financial year.

According to the purpose of this study and the literature review, we use a set of factors that determine information asymmetry to assess the ability of the proposed model to generalize based on the sample. Therefore, the general model includes the spread as an endogenous variable, which corresponds to a series of share purchase and sale prices of the sample companies. The spread has been measured in four ways;

(i) the annual average of the differences between both prices (Spread_A_B),

(ii) the annual average of the natural logarithm of the differences between both prices (Ln_Average_Spread), 
(iii) the average spread weighted by the stock quantity traded (Weighted_Spread), and

(iv) the annual average of the differences between both prices divided by its average value (Average_Spread). Gjerde, Mahenthiran and Cademartori (2013) annualized the spread using the ratio of the absolute value of daily return, divided by daily cash volume, then weighted and summed over the number of days in the year in which a trade occurs.

The magnitude of the four variables of spread are different (Table 2). Weighted_Spread and Simple_Spread have significantly larger magnitudes comparing to the others two variables. Similarly the differences in the four statistical moments are also great.

Table 2.

Descriptive analysis of variables of spread

\begin{tabular}{lrrrr}
\hline \hline & Weighted_Spread & Simple_Spread & Average_Spread & Ln_Average_Spread \\
\hline $\mathrm{N}$ & 2002746 & 2002746 & 2002746 & 2002746 \\
Mean & 3004468254 & 1296432846 & 0.006675241 & 0.00669037 \\
Standard deviation & 7929492038 & 5661541091 & 0.013682464 & 0.01676721 \\
Skewness & 3513965943 & 4120631873 & 2603666214 & 145355836 \\
Kurtosis & 4726756606 & 2594936244 & 2037467199 & 529968225 \\
Minimun & 0 & 0 & 0 & 0 \\
Maximun & 17820399.77 & 4770 & 19957716 & 6851185 \\
\hline \hline
\end{tabular}

Source: Authors' calculations.

A cross-sectional model, using the ordinary least squares method, for this empirical application was used in which the companies and periods were combined for each of the model's cross sections. And we also used different ways to measure the endogenous variable, presenting the results for each of the four models obtained in the Table 4.

The general model in its functional form is specified by the following equation:

$$
\begin{aligned}
& \text { Spread }_{\mathrm{i}}=\beta_{0}+\beta_{1}{ }^{*} \text { Sale_Quant }_{\mathrm{i}}+\beta_{2}{ }^{*} \text { Pur_Quant }_{\mathrm{i}}+\beta_{3}{ }^{*} \mathrm{IFRS}_{\mathrm{i}}+\beta_{4}{ }^{*} \text { Mean_Dis }_{\mathrm{i}}+ \\
& +\beta_{5}{ }^{*} \text { Kurtosis_DIS }_{\mathrm{i}}+\beta_{6}{ }^{*} \text { Leverage }_{\mathrm{i}}+\beta_{7}{ }^{*} \text { Ln_Assets }_{\mathrm{i}}+\beta_{8}{ }^{*} \text { ADR_Issue }_{\mathrm{i}}+\beta_{9}{ }^{*} \text { IPSA }_{\mathrm{i}}+ \\
& +\beta_{10} * \text { Own_5_Shareholders }{ }_{\mathrm{i}}+\beta_{11} * \text { Own_InstInv_PF }_{\mathrm{i}}+\beta_{12} * \text { Botosan }_{\mathrm{i}}+\mu_{\mathrm{i}}
\end{aligned}
$$

where:

- Spread $_{\mathrm{i}}$ : the difference between of the share purchase and sale price for the sample companies,

- Sale_Quant: the quantity offered for the sale of sample company shares,

- Pur_Quant the quantity offered for the purchase of sample company shares,

- IFRS $_{i}$ : the dichotomist variable that sums the value of 1 if company "i" adopts IFRS and 0 in the contrary case,

- Mean_DIS : the sample company information disclosure index (calculated by mean value),

- KurtosisDIS : the sample company information disclosure index (calculated by the kurtosis),

- Leverage $_{i}$ : the leveraging of the sample companies' debt,

- Ln_Assets: the natural logarithm of the sample companies' assets,

- ADR_Issue ${ }_{i}$ : the dichotomist value that assumes the value of 1 if company " $i$ " issues ADR and 0 in the contrary case,

- IPSA ${ }_{\mathrm{i}}$ : the dichotomist value that assumes the value of 1 if company "i" is traded on the SSPI and 0 in the contrary case, 
- Own_5_Shareholders : the ownership percentage of the five main shareholders of the sample companies,

- Own_Inst_Inv_PF: the participation of institutional investors in the ownership of the sample companies, particularly in the case of pension funds (PF),

- Botosan $:$ the sample company information disclosure index, we use the value obtained by calculating the 138 items and,

- $\mu_{\mathrm{i}}$ : random error.

Table 3 shows the primary data from the exploratory analysis of the continuous exogenous variables presented in the empirical analysis. The Table shows that the values of the variables are fairly heterogeneous. Certain variables (Sale_Quant and Pur_Quant) have values that are substantially higher than in the case of other variables (i.e., Kurtosis_DIS and Leverage). Additionally, the level of ownership concentration of sample company shareholders is notable. The average percentage share of the five main shareholders is $70 \%$, and the company with the highest ownership concentration (the telecom CTC-A) boasts $98.5 \%$. The percentages of ownership participation of the institutional investors, pension funds (Own_Inst_Inv_PF) amount to an average of $6.5 \%$, with a ceiling of $26 \%$ (the case of Aguas Andina S.A., whose shares are denoted Aguas-A).

Table 3.

Descriptive analysis of continuous model exogenous variables

\begin{tabular}{lcccccc}
\hline & Mean & Maximum & Minimum & Stand. Dev. & Asymmetry & Kurtosis \\
\hline Sale_Quant & 26683.21 & 150401.2 & 1142669 & 33196.39 & 1791883 & 5522053 \\
Pur_Quant & 25468.10 & 162203.1 & 1193516 & 33179.99 & 1999314 & 6670038 \\
Mean_DIS & 0.602124 & 0.741176 & 0.482353 & 0.068438 & 0.085244 & 2473136 \\
Kurtosis_DIS & -0.971111 & 0.190170 & -1833589 & 0.475957 & 0.764296 & 3087189 \\
Leverage & 0.912788 & 1566445 & 0.509735 & 0.252914 & 0.557354 & 2782955 \\
Botosan & 3724306 & 5550000 & 2500000 & 6957615 & 0.372145 & 2200716 \\
Ln_Assets & 2091857 & 2310814 & 1467406 & 1721432 & -2366565 & 9771537 \\
Own_5_Shareholders & 6961917 & 9850000 & 7690000 & 1821537 & -0.730911 & 3758112 \\
Own_Inst_Inv_PF & 6502986 & 2647000 & 0.000000 & 6758253 & 1115546 & 3610577 \\
\hline \hline
\end{tabular}

Source: Authors' calculations.

\section{RESULTS}

The results of the four models with endogenous variable measured by: Spread_A_B, Ln_Average_Spread, Weighted_Spread, and Average_Spread, are shown in Table 4 and Table 5. Table 5 presents results of the accuracy of the adjustment for these models, observing the fit indices (coefficient of determination and adjusted coefficient of determination) we can see that, despite that the Weighted_Spread model has the best adjustment index, the Ln_Average_Spread model has the highest number of significant coefficients. This model also shows a good quality of adjustment measure by the criterion of Akaike, Schwarz and Hannan-Quinn. Thus the best model to represent the variability of the asymmetry of information through the spread is that in which the endogenous variable is measured through the difference of the logarithm of the share purchase and sale price for the sample companies. 
For this model, the results presented in Table 4 enable us to observe the individual significance levels and the joint levels for model variables at $95 \%{ }^{2}$, with the exception of the variables Ln_Assets and Botosan, which are $90 \%$ significant. The variability of the endogenous variable is explained in $56 \%$ of the sample by the variability of the exogenous variables. Additionally, the model presents adequate information criteria (Akaike, Schwarz, Hannan-Quinn ${ }^{3}$ ). The hypotheses associated with the model residuals do not present residual autocorrelation ${ }^{4}$ or heteroscedasticity problems ${ }^{5}$.

Table 4.

Estimation results of different endogenous variables

$\begin{array}{lccccccccc}\text { Endogenous variable Spread_A_B model } & & & & & & \\ \text { Variable } & \text { Sale_Quant } & \text { IFRS } & \text { Kurtosis_DIS } & \text { Ln_Assets } & \text { IPSA } & \text { Own_Inst_Inv_PF } & \text { Botosan } & \text { C } \\ \text { Coefficient } & -0.000559 & 1316211 & -9996496 & -2509044 & -2527352 & -1594019 & -1598691 & 1760416 \\ \text { Stand. Dev. } & 0.000161 & 1129104 & 1131181 & 3370909 & 1530891 & 0.812351 & 0.777754 & 7176484 \\ \text { t-statistic } & -3468546 & 0.116571 & -0.883722 & -0.744323 & -1650902 & -1962229 & -2055524 & 2453034 \\ \text { P-value } & 0.0009 & 0.9076 & 0.3802 & 0.4594 & 0.1037 & 0.0541 & 0.0439 & 0.0169\end{array}$

Endogenous variable Ln_Average_Spread model

$\begin{array}{lcccccccc}\text { Variable } & \text { Sale_Quant } & \text { IFRS } & \text { Kurtosis_DIS } & \text { Ln_Assets } & \text { IPSA } & \text { Own_Inst_Inv_PF } & \text { Botosan } & \text { C } \\ \text { Coefficient } & -6.44 \mathrm{E}-08 & -0.008294 & -0.003138 & -0.001144 & -0.020018 & -0.000680 & -0.000285 & 0.073754 \\ \text { Stand. Dev. } & 3.15 \mathrm{E}-08 & 0.002207 & 0.002211 & 0.000659 & 0.002993 & 0.000159 & 0.000152 & 0.014030 \\ \text { t-statistic } & -2044404 & -3757 & -1418986 & -1736439 & -6688553 & -4283220 & -1874882 & 5256831 \\ \text { P-value } & 0.0450 & 0.0004 & 0.1608 & 0.0873 & 0.0000 & 0.0001 & 0.0654 & 0.0000\end{array}$

Endogenous variableWeighted_Spread model

\begin{tabular}{lccccccccc} 
Variable & Sale_Quant & IFRS & Kurtosis_DIS & Ln_Assets & IPSA & Own_Inst_Inv_PF & Botosan & C \\
Coefficient & $-5.73 \mathrm{E}-08$ & -0.007219 & -0.003130 & -0.001007 & -0.018775 & -0.000570 & -0.000169 & 0.062779 \\
Stand. Dev. & $2.68 \mathrm{E}-08$ & 0.001876 & 0.001879 & 0.000560 & 0.002544 & 0.000135 & 0.000129 & 0.011923 \\
t-statistic & -2139891 & -3848 & -1665459 & -1797226 & -7381336 & -4223234 & -1309305 & 5265158 \\
P-value & 0.0362 & 0.0003 & 0.1007 & 0.0770 & 0.0000 & 0.0001 & 0.1951 & 0.0000 \\
\hline
\end{tabular}

Endogenous variable Average_Spread model

\begin{tabular}{lccccccccc} 
Variable & Sale_Quant & IFRS & Kurtosis_DIS & Ln_Assets & IPSA & Own_Inst_Inv_PF & Botosan & C \\
Coefficient & $-4.27 E-07$ & -0.009906 & -0.030265 & -0.001574 & -0.114091 & -0.002722 & 0.000448 & 0.148765 \\
Stand. Dev. & $2.01 \mathrm{E}-07$ & 0.014086 & 0.014112 & 0.004205 & 0.019099 & 0.001013 & 0.000970 & 0.089531 \\
t-statistic & -2124252 & -0.703205 & -2144594 & -0.374363 & -5973718 & -2686135 & 0.461850 & 1661606 \\
P-value & 0.0375 & 0.4845 & 0.0358 & 0.7094 & 0.0000 & 0.0092 & 0.6458 & 0.1015 \\
\hline \hline
\end{tabular}

Source: Authors' calculations.

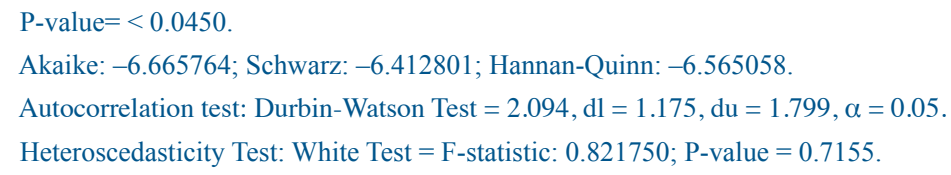


Table 5.

Summary estimation results of different endogenous variables

\begin{tabular}{lcccccc}
\hline \hline \multicolumn{1}{c}{$\begin{array}{c}\text { Endogenous } \\
\text { variable }\end{array}$} & $\begin{array}{c}\text { Number } \\
\text { of Significant } \\
\text { Coefficient (90\%) }\end{array}$ & $\begin{array}{c}\text { Determination } \\
\text { Coefficient }\end{array}$ & $\begin{array}{c}\text { Adjusted } \\
\text { Coefficient } \\
\text { of Determination }\end{array}$ & $\begin{array}{c}\text { Akaike } \\
\text { Criterion }\end{array}$ & $\begin{array}{c}\text { Schwarz } \\
\text { Criterion }\end{array}$ & $\begin{array}{c}\text { Hannan- } \\
\text { Quinn } \\
\text { Criterion }\end{array}$ \\
\hline Spread_A_B & 4 & 0.29 & 0.22 & 10414 & 10667 & 10519 \\
Ln_Average_Spread & 7 & 0.56 & 0.51 & -6666 & -6413 & -6565 \\
Weighted_Spread & 6 & 0.58 & 0.53 & -6991 & -6738 & -6890 \\
Average_Spread & 4 & 0.44 & 0.38 & -2959 & -2706 & -2858 \\
\hline \hline
\end{tabular}

Source: Authors' calculations.

Table 4 shows that the sign of the sale quantity of sample company shares (Sale_Quant) is coherent with economic theory (Demsetz, 1968). Thus, for each unit by which the sale quantity is increased, the spread value of the sample companies decreases by $6.44 \mathrm{E}-06 \%$.

Regarding the measurement of the quality of corporate governance in each of the sample companies, measured by Kurtosis_DIS and Botosan, and its effect on information asymmetry, the signs were as expected. That is, at a higher level of sample company corporate governance, information asymmetry is lower, all other variables remaining equal. These results are in concordance with Cormier, Ledoux, Magnan and Aerts, W. (2010), they conclude that good corporate governance practice, such as board size and audit committee and voluntary governance disclosure, reduce asymmetry of information. The same reasoning is shown in Bakhshi, Bazrafshan, Rezaei and Fereidouni (2011).

As for the qualitative variable that measures IFRS adoption (IFRS) for each of the sample companies, when companies adopt international accounting standards, they have less information asymmetry than they would have in the contrary case because more information disclosure (primarily expressing assets, liabilities and equity in economic and not historical values) generates less information asymmetry for investors, which results in a lower spread (ceteris paribus the others factors). This result agrees with Assidi and Omri (2012), because they find that adoption of IFRS mitigate the asymmetry of information. Regarding the listing of sample companies on the IPSA, when a company belongs to this index, information asymmetry measured by the spread decreases by $2 \%$ compared with companies that were not listed on the IPSA during the study period.

Regarding control variables, for the natural logarithm variable of assets (Ln_Assets) as a measure of company size, larger companies have more resources to develop stronger corporate governance structures. Therefore, they disclose more information, which decreases information asymmetry and lowers the spread (all other variables remaing equal).

The negative effect of the control variable PF institutional investor ownership (Own_ Inst Inv_PF) on the spread can be explained by the fact that a greater participation of institutional investors in the ownership of companies leads them to fulfill a fiduciary role and to safeguard the quality of corporate governance and the adequate use of contributed resources, which in turn increases trust among investors. Therefore, the difference between the purchase and sale value of a share (spread) is smaller.

There is a strong correlation between two variables, shares sale quantity (Sale_Quant) and shares purchase quantity (Pur_Quant), in the sample companies. Therefore, the variable shares sale quantity captures information provided by the variable shares purchase quantity ${ }^{6}$. A similar conclusion was reached by Copeland and Galai (1983): they conclude that the Bid-Ask spread increases with greater price volatility in the asset being traded, with a higher asset price level,

Correlation Coefficient $=0.992140$, P-value $=0.0000$. 
and with lower volume. Other non-significant variables included in the study are the following: whether the company issues ADRs, the level of leveraging of a sample company's debt (Leverage) and the ownership percentage of the five main shareholders of sample companies. As for the latter, a high concentration of ownership in the hands of the five main shareholders may not be significant. Although they share among themselves important information that they would not be willing to publish without appropriate regulations, the legislation and regulations of the SVS forces the companies to issue an information handling manual, which is of interest to the market ${ }^{7}$. This phenomenon can largely explain the small significance of the other variables.

\section{CONCLUSIONS AND RESEARCH IMPLICATIONS}

This study has used different models to measure the relation between: variables related to the quality of corporate governance, control variables, with the spread. To validate the above relations different measures of spread were used, for which different econometric models have been used. We find that the different ways for measuring the spread is not indifferent, affecting the goodness of fit of the proposed models.

Regarding the paper's hypotheses, the definition of spread used affects the robustness of the model, so, when we used the natural logarithm of the differences between ask and bid prices as a measure of the spread, it has the best indicators of goodness of fit of all models tested, which supports hypothesis 1 . And, the method used to annualize intra-day data affects the robustness of the model, so, in our case when we annualize our intra-day data, as the annual average of the natural logarithm of the differences between ask and bid prices, we obtain the best fit of our model, which supports hypothesis 2 .

When the sample is extended to all of the companies that were listed on the IPSA at any time during the study period, the general model variables will still be incorporated and may possess increased relevance for future research as information disclosure regulations and other issues of corporate governance are strengthened. This will give us the opportunity to try other kinds of models, perhaps using multivariate time series methodology or panel data models (de la Fuente et al., 2015; Coughenour et al., 2016).

Thus, the Chilean market shows similar characteristics of other emerging markets, where there is high ownership concentration, lower liquidity, and lack of transparency.

The finding suggests that regulators should produce new regulations to improve the quality of corporate governance and the information disclosed to the market in order to reduce information asymmetry and make the Chilean market more efficient and this also holds for other emerging markets.

\section{References}

Amihud, Y. and Mendelson, H. (1989). The Effects of Beta, Bid-Ask Spread, Residual Risk, and Size on Stock Returns. The Journal of Finance, 44(2), 479-486.

Armstrong, C.S., Barth, M.E., Jagolinger, A.D. and Riedl, E.J. (2010). Market Reaction to the Adoption of IFRS in Europe. The Accounting Review, 85(1), 31-61.

Assidi, S. and Omri, M.A. (2012). IFRS and Information Quality: Cases of CAC 40 Companies. Global. Journal of Management and Business Research, 12(19), 72-83.

Bakhshi, M., Bazrafshan, E., Rezaei, M. and Fereidouni, H.G. (2011). The Impact of Corporate Governance on the Bid-Ask Spread: Evidence from an Emerging Market. International Conference on Sociality and Economics DevelopmentIPEDR vol. 10 (2011) C (2011) IACSIT Press, Singapore. Recuperado de http://www.ipedr.com/ vol10/97-S10064.pdf

The information handling manual is required by General Norm No. 211 (SSI, 2008) and the Mercado de Valores Law No. 18.045. 
Benston, G. and Hagerman, R. (1974). Determinants of Bid-Ask spreads in the over-the-counter market. Journal of Financial Economics, 1, 353-364.

Bollen, N.P.B., Smith T. and Whaley, R. (2004). Modeling the bid/ask spread: measuring the inventory-holding premium. Journal of Financial Economics, 72(1), 97-141.

Botosan, C.A. (1997). Disclosure Level and The Cost of Equity Capital. The Accounting Review, 72(3), 323-349.

Chan, K. and Chung, P. (2012). Asymmetric Price Distribution and Bid-Ask Quotes in the Stock Options Market. Asia-Pacific. Journal of Financial Studies, 41, 87-102.

Chen, W.P., Chung, H., Lee, C. and Liao, W.L. (2007). Corporate Governance and Equity Liquidity: analysis of S\&P transparency and disclosure rankings. Corporate Governance: An International Review, 15(4), 644-660.

Chung, H. (2006). Investor protection and the liquidity of cross-listed securities: Evidence from the ADR market. Journal of Banking and Finance, 30, 1485-1505.

Coloma, F. (2010). Desafíos de la Regulación de Gobiernos Corporativos en Chile. Superintendente de Valores y Seguros. [Challenges of Corporate governance regulations in Chile.] Superintendente de Valores and Seguros. Corporate governance presentation.

Copeland, T.E. and Galai, D. (1983). Information Effects on the Bid-Ask Spread. The Journal of Finance, 38(5), $1457-1469$.

Cormier, D., Ledoux, M.J., Magnan, M. and Aerts, W. (2010). Corporate governance and information asymmetry between managers and investors. Corporate Governance, 10(5), 574-589.

Corwin, S.A. and P. Schultz (2012). A Simple Way to Estimate Bid-Ask Spreads from Daily High and Low Prices. The Journal of Finance LXVII, (2): 719-759.

Coughenour, C., Paz, A., De la Fuente, H. and Singh, A. (2016). Multinomial logistic regression to estimate and predict perceptions of bicycle and transportation infrastructure in a sprawling metropolitan area. Journal of Public Health, 38(4), e401-e408, doi: 10.1093/pubmed/fdv179.

De la Fuente, H., Paz, A., Conover, R. and Khan, A. (2015). Forecasting of financial series for the Nevada department of transportation using deterministic and stochastic methodologies. Procedia Manufacturing, 3, 3317-3324.

Demsetz, H. (1968). The Cost of Transacting. The Quarterly Journal of Economics, 82(1), 33-53.

Dennis, P. and Weston, J. (2001). Who's Informed? An Analysis of Stock Ownership and Informed Trading (June 4, 2001). AFA 2002 Atlanta Meetings. Available at SSRN: http://ssrn.com/abstract=267350 or http://dx.doi. org/10.2139/ssrn. 267350

Economía and Negocios (2012). Director independiente de Enersis solicita a la SVS que precise tiempos para pronunciarse. [Independent director of Enersis requests the SVS to specify ruling times] (October 24), available athttp://www.economiaynegocios.cl/noticias/noticias.asp?id=101888

Florou, A. and Pope, P. (2012). Mandatory IFRS Adoption and Institutional Investment Decisions. The Accounting Review, 87(6), 1993-2025.

Fu, R., Kraft, A. and Zhang, H. (2012). Financial reporting frequency, information asymmetry, and the cost of equity. Journal of Accounting and Economics, 54(2), 132-149.

Gigler, F. and Hemmer, T. (1999). On the frequency, quality, and informational role of mandatory financial reports. Journal of Accounting Research, 36, 117-147.

Ghoul, S.E., Guedhami, O., Ni, AND., Pittman, J. and Saadi, S. (2013). Does Information Asymmetry Matter to Equity Pricing? Evidence from Firms' Geographic Location. Contemporary Accounting Research, 30(1), 140-181.

Gjerde, T., Mahenthiran, S. and Cademartori, D. (2013). Effect of ownership, governance, and transparency on liquidity - Chilean evidence. Journal of Contemporary Accounting and Economics, 9(2), 183-202.

Glosten, L.R. and Harris, L.E. (1988). Estimating the Components of the BID/ASK Spread. Journal of Financial Economics, 21(1), 123-142.

Gompers, P., Ishi, J. and Metrick, A. (2003). Corporate Governance and Equity Prices. The Quarterly Journal of Economics, 118(1), 107-155.

Greenstein, M.M. and Sami, H. (1994). The Impact of the SEC's Segment Disclosure Requirement on Bid- Ask Spreads. The Accounting Review, 69(1), 179-199.

Haat, H.M., Mahenthiran, S., Rahman A.R. and Hamid A.N. (2006). Agency Costsas a Factor in the Suspension of Companies from the Kuala Lumpur Stock Exchange, Journal of Contemporary Accounting and Economics, 2(1), 99-121.

Harris, L. (1990). "Statistical Properties of the Roll Serial Covariance Bid/Ask Spread Estimator." The Journal of Finance LXV (No. 2): 570-590.

Healy, P.M. and Palepu, K.G. (2001). Information asymmetry, corporate disclosure, and the capital markets: A review of the empirical disclosure literature. Journal of Accounting and Economics, 31(1-3), 405-440.

Kanagaretnam, K., Lobo, G. and Whalen, D. (2007). Does good corporate governance reduce information asymmetry around quarterly earnings announcements? Journal of Accounting and Public Policy, 26(4), 497-522.

Karpoff, J.M. (1987). The relation between price changes and trading volume: a survey. Journal of Financial and Quantitative Analysis 22 (1), 109-126. 
Khurana, I.K., Pereira, R. and Martin, X. (2006). Firms Growth and Disclosure: An Empirical Analysis. Journal of Financial and Quantitative Analysis, 41(2), 357-380.

Kothari, S.P., Leone A. and Wasley, C. (2005). Performance Matched Discretionary Accrual Measures. Journal of Accounting and Economics, 39, 163-197.

Kunkel, G. (1982). Sufficient conditions for public information to have social value in a productionand exchange economy. Journal of Finance 37, 1005-1013.

Lin, J.C., Sanger, G.C. and Booth, G.G. (1995). Trade Size and Components of the Bid-Ask Spread. The Review of Financial Studies, 8e Journal of Financial and Quantitative Analysis 4 (4), 347-400.

Marshall, J.M. (1974). Private incentives and public information. The American Economic Review64, 373-390.

McInish, T. and Wood, R. (1992). An Analysis of Intraday Patterns in Bid/Ask Spreads for NYSE Stocks. The Journal of Finance, 47(2), 753-764.

Munteanu, L. (2011). Cost of Equity, Financial Information Disclosure, and IFRS adoption: A Literature Review. Internal Auditing and Risk Management, 4(24), 67-80.

Organization for Economic Cooperation and Development (OECD). (2011). Strengthening Latin American Corporate governance. The role of institutional investors, $1-80$.

Rapaport, M. and Sheng, H.H. (2010). Ownership structure and firm value in Brazil. Revista Latinoamericana de Administración, 45, 76-95.

Roll, R. (1984). A Simple Implicit Measure of the Effective Bid-Ask Spread in an Efficient Market, The Journal of Finance XXXIX, (4): 1127-1139.

Rubin, A. (2007). Ownership Level, Ownership Concentration and Liquidity. Journal of Financial Markets, 10(3), 219-248.

Sarin, A., Shastri, K. and Shastri, K. (1996). Ownership structure and stock market liquidity. Available at SSRN: http://ssrn.com/abstract=2652

Soderstrom, N.S. and Sun, K.J. (2007). IFRS Adoption and Accounting Quality: A Review. European Accounting Review, 16(4), 675-702.

Standard and Poor's. (2006). Standard and Poor's Corporate Governance Scores, Criteria, Methodology and Definitions.

Superintendencia de Valores and Seguros (SVS) (2008). Norma de Carácter General 211. Establece normas para la publicidad de políticas y procedimientos relativos al manejo y divulgación de información para el mercado [General Regulation211. Establishing regulations for publishing policies and procedures for handling and disclosing market information.] Issued 15 January 2008.

Trueman, B. (1986). Why do managers voluntarily release earnings forecasts? Journal of Accounting and Economics $8(1), 53-71$.

Venkatesh, P.C. and Chiang, R. (1986). Information Asymmetry and the Dealer's Bid-Ask Spread: A Case Study of Earnings and Dividend Announcements. The Journal of Finance, 41(5), 1089-1102.

Verrecchia, R. (2001). Essays on disclosure. Journal of Accounting and Economics, 32(1-3), 97-180. 